I 19.2: $645 / 4$

U.S. Department of the Interior/Geological Survey

\title{
Glaciers: \\ Clues to Future Climate?
}

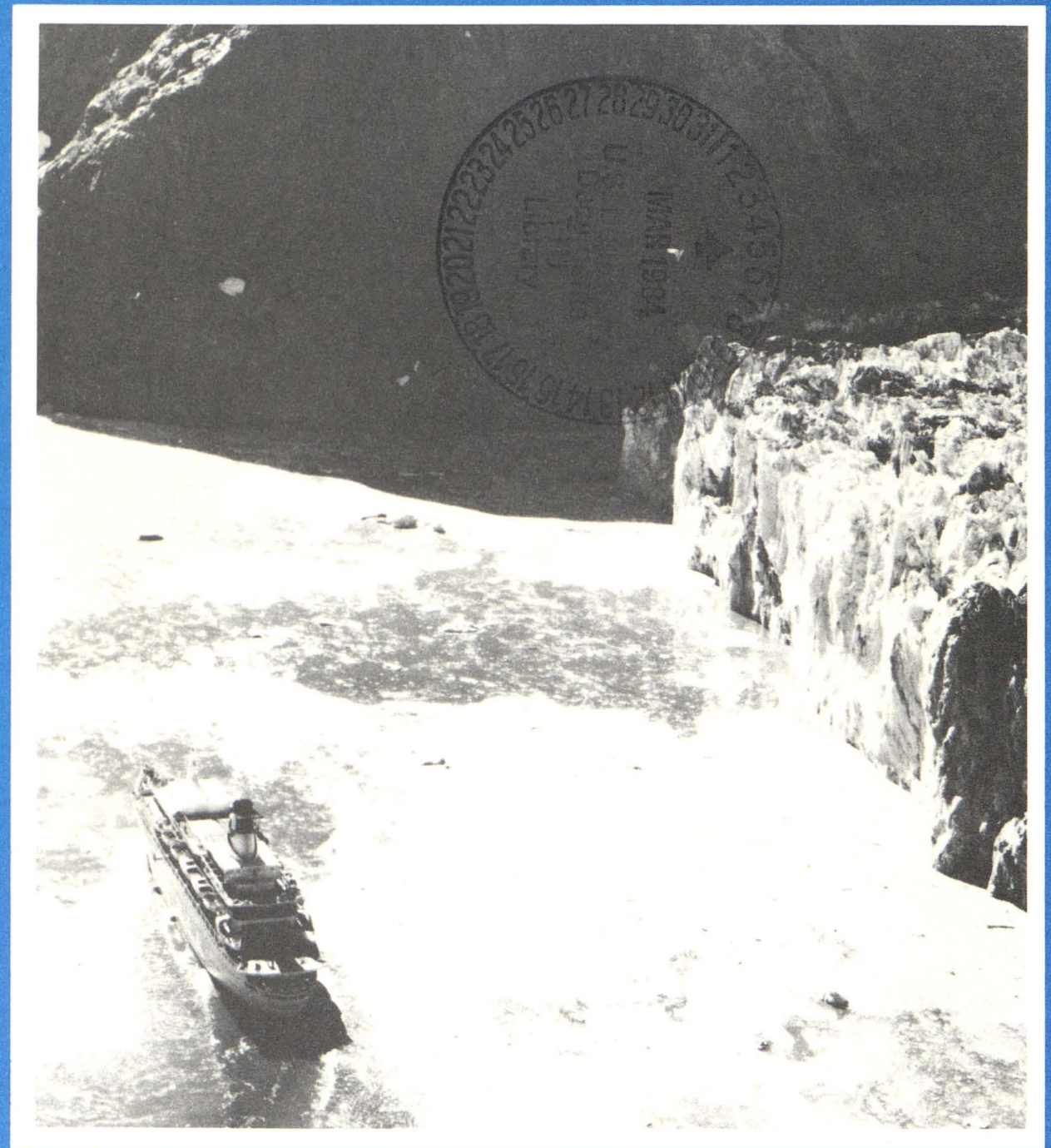




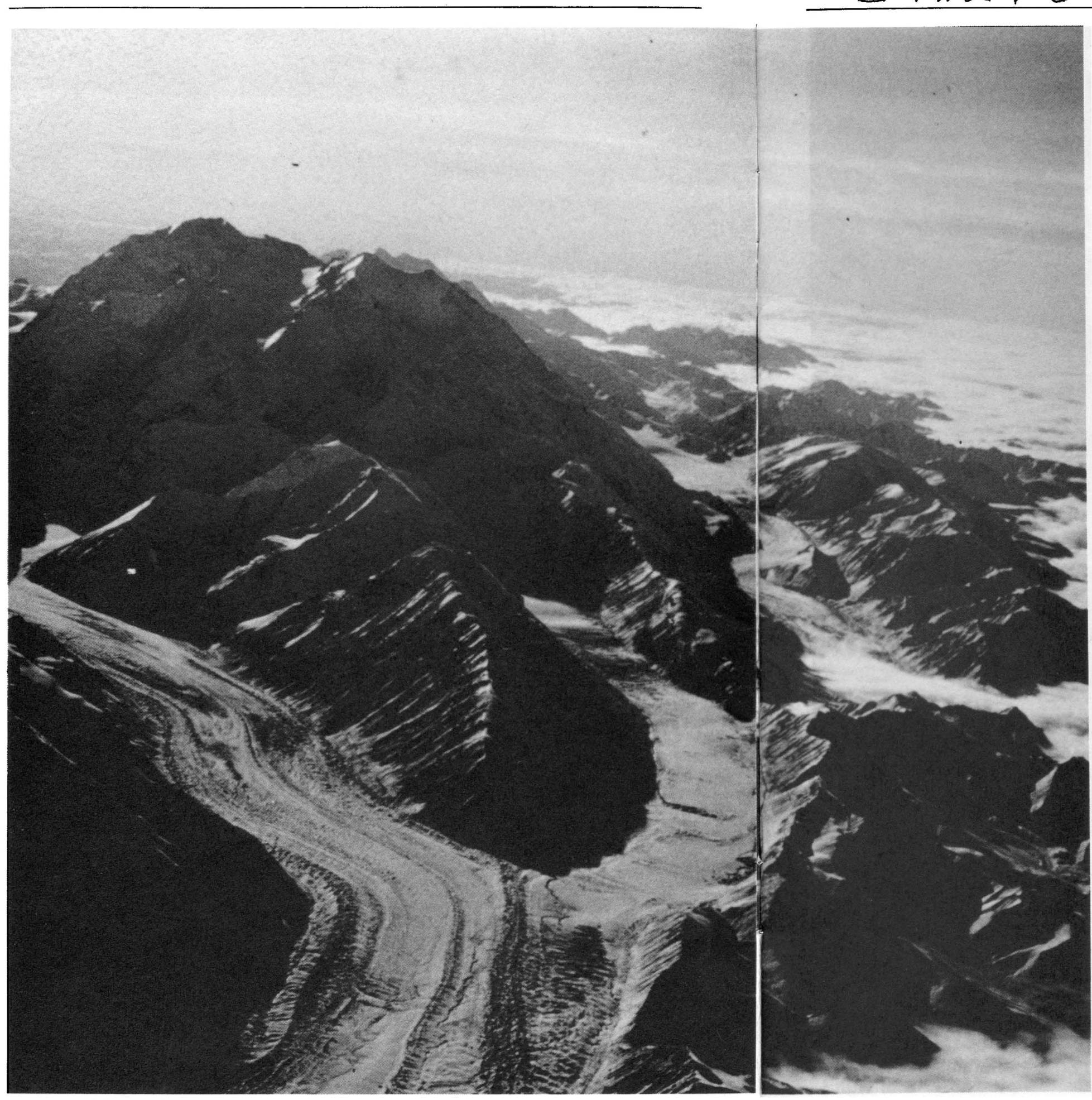

Cover photograph:

The ship Island Princess and the calving terminus of Johns Hopkins Glacier, Glacier terminus of Johns Hopkins Glacier, Glacier aerial photo by Austin Post, Sept. 2, 1977)

Oblique aerial photo of valley glaciers in Mt. McKinley National Park, Alaska (photo by Richard S. Williams, Jr., Oct. 4, 1965) 


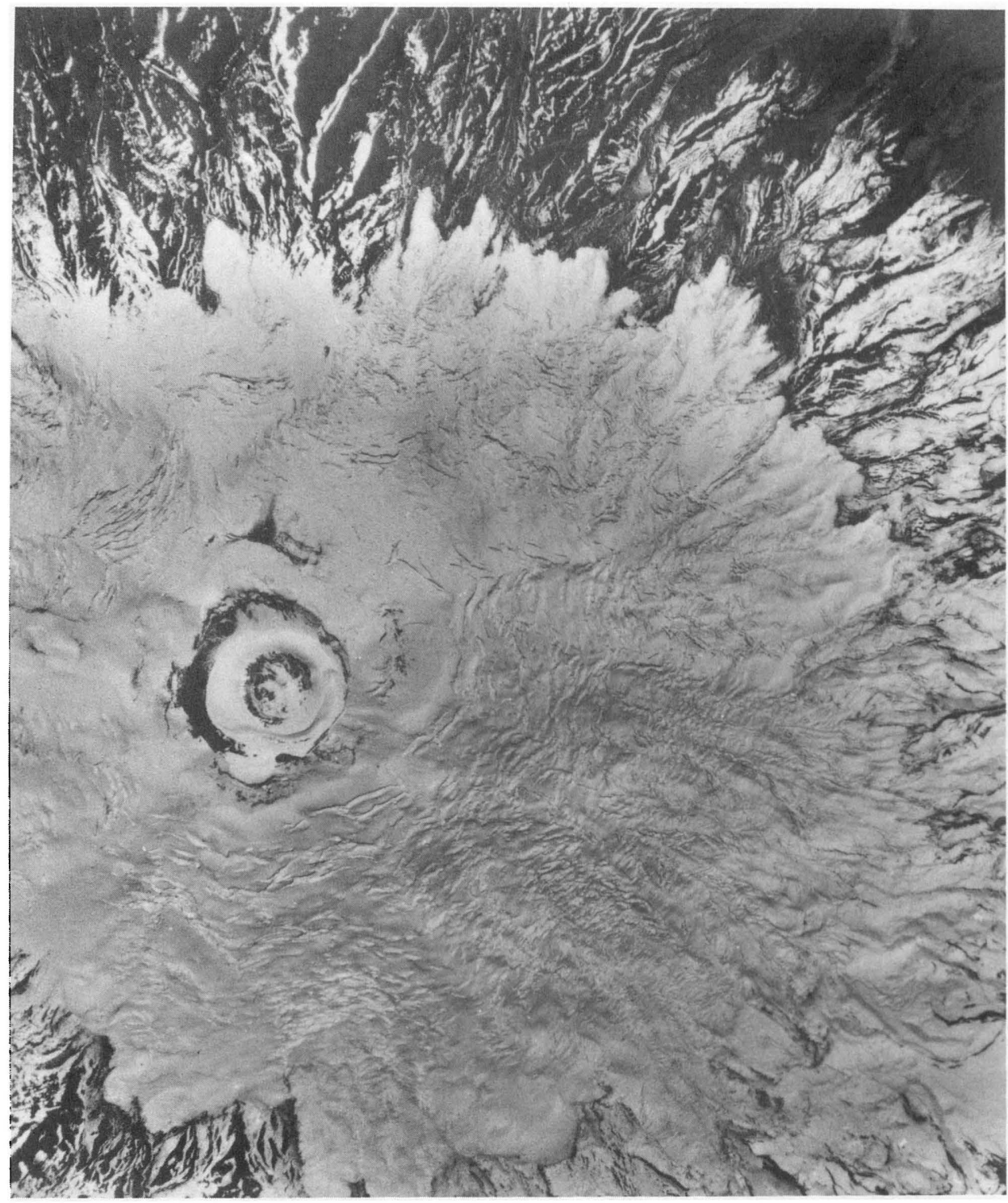

Vertical aerial photo of severely crevassed glaciers on the slopes of Cotopaxi, a nearly symmetrical volcano, near the Equator in north-central Equador (photo courtesy of U.S. Air Force).

A glacier is a large mass of ice having its genesis on land and represents a multiyear surplus of snowfall over snowmelt. At the present time, perennial ice covers about 10 percent of the land areas of the Earth. Although glaciers are generally thought of as polar entities, they also are found in mountainous areas throughout the world, on all continents except Australia, and even at or near the Equator on high mountains in Africa and South America. 


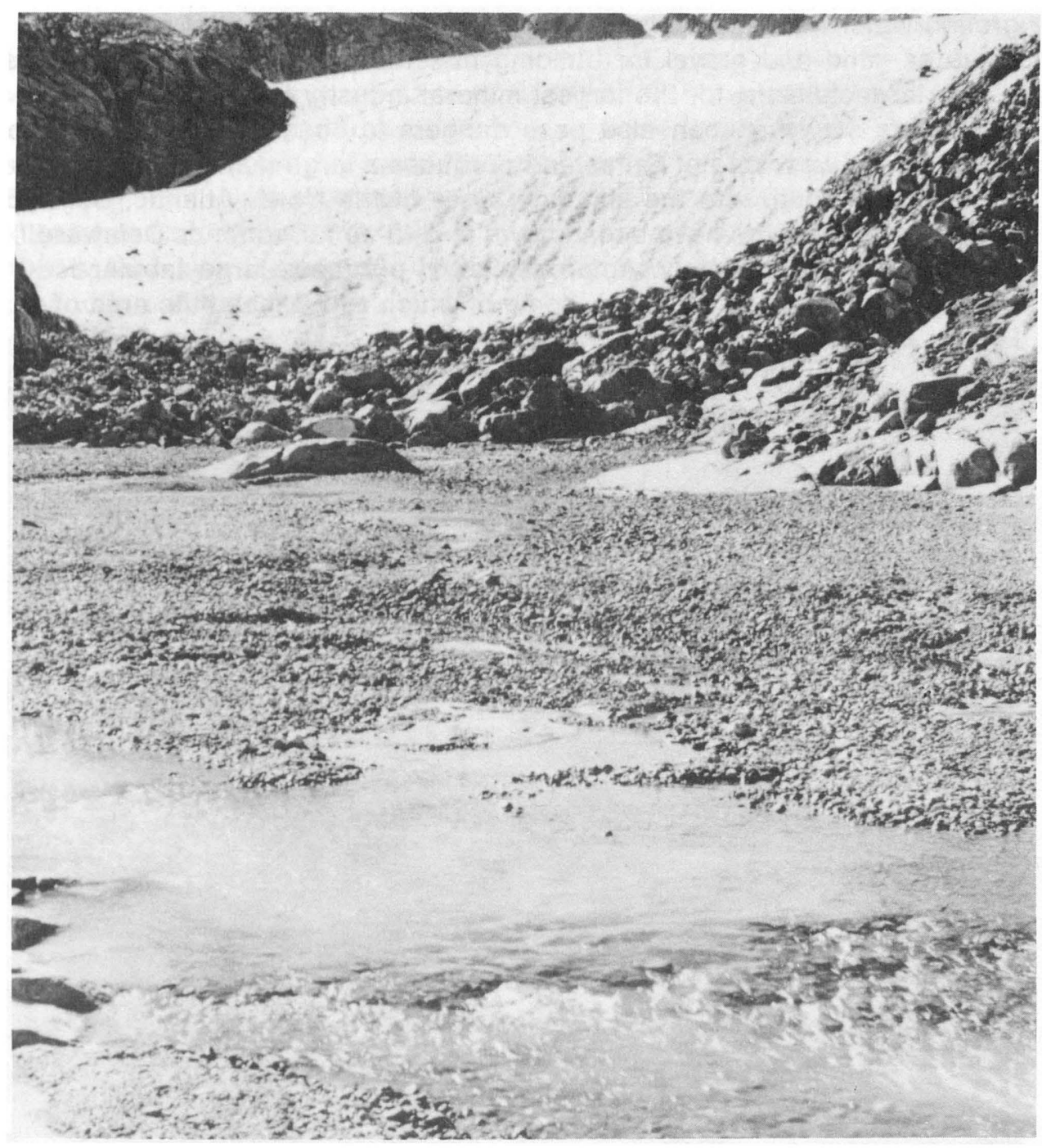

Streamflow from the terminus of the Mammoth Glacier, Wind River Range, Montana (photo by Mark F. Meier, August 1950).

Present-day glaciers and the deposits from more extensive glaciation in the geological past have considerable economic importance in many areas. In areas of limited precipitation during the growing season, for example, such as parts of the Western United States, glaciers are considered to be frozen freshwater reservoirs which release water during the drier summer months. In the Western United States, as in many other mountainous regions, they are of considerable economic importance in the irrigation of crops and to the generation of hydroelectric power. Lakes and ponds are numerous where continental ice sheets once covered New England and the upper Midwest, and the glacial deposits act as major 
ground-water reservoirs. The same deposits have substantial economic value as sand and gravel for building materials, and are often the basis, as in Massachusetts, for the largest mineral industry in a State.

Glaciers, however, can also pose dangers to ocean transportation. For example, the west side of Greenland produces a large number of icebergs which travel south into the shipping lanes of the North Atlantic. Some of Greenland's icebergs have been known to drift as far south as Delaware before melting completely. Antarctica often produces large tabular icebergs from its many ice shelves, some of which may exceed the area of Rhode Island.

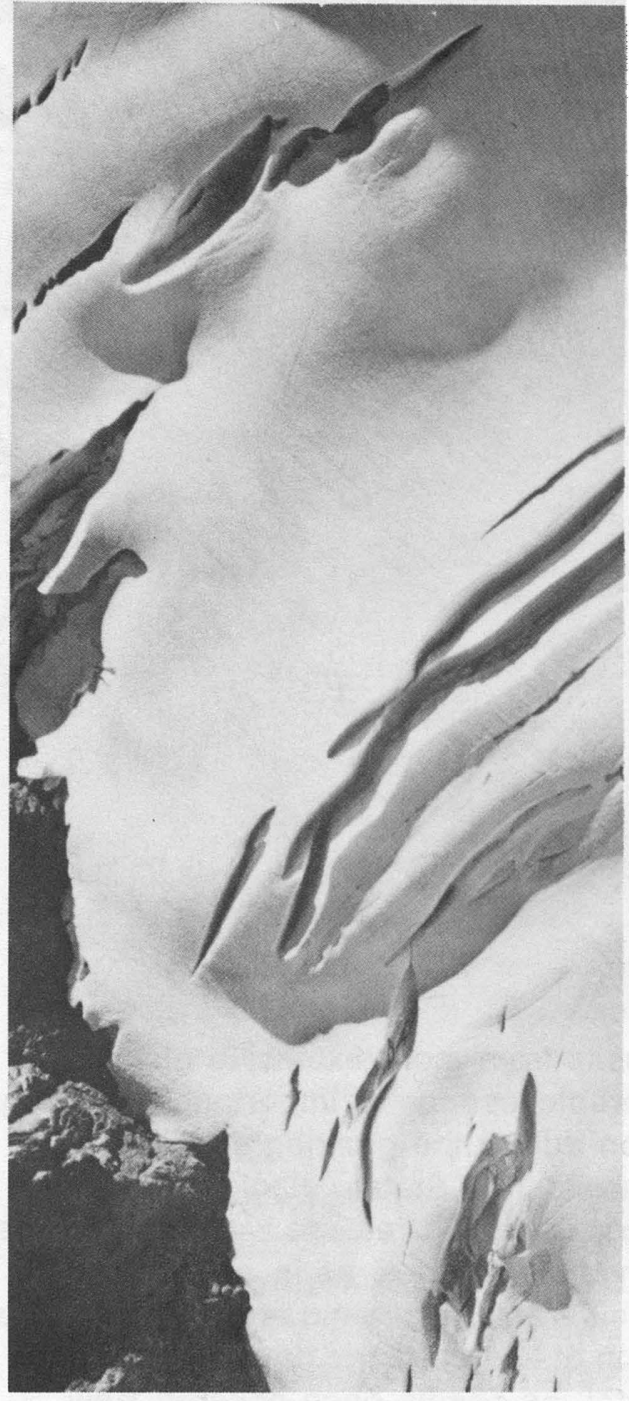

Oblique aerial view of crevasses at an icefall on Le Conte Glacier, Washington.

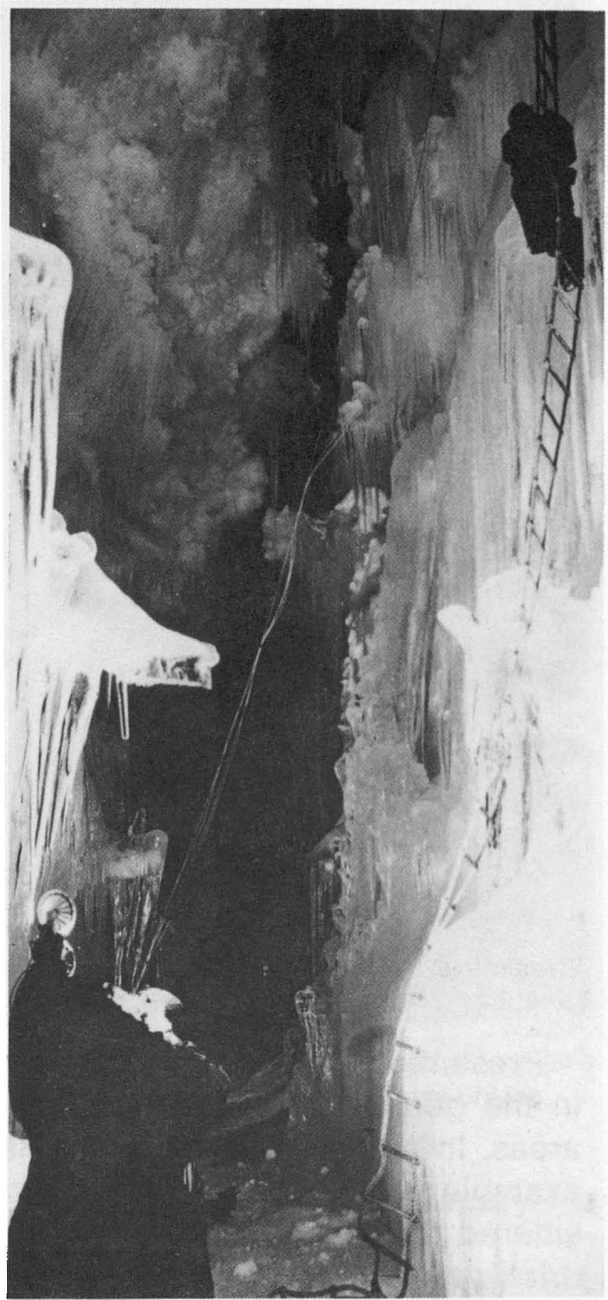

Interior view of a crevasse in Blue Ice Valley on the Greenland Ice Sheet: A glaciologist can be seen descending a rope ladder, 65 feet (20 meters) below the ice sheet surface (August 1955). 
In Alaska, glaciologists of the U.S. Geological Survey have carried out a long-term study of the rate of retreat of the Columbia Glacier. This large valley glacier's snout ends as a tidal glacier in Prince William Sound, a waterway traversed by large oil tankers en route to and from Valdez, the southern terminus of the trans-Alaskan pipeline. In 1980, U.S. Geological Survey glaciologists predicted that the 425-square-mile (1100-squarekilometer) Columbia Glacier would begin an accelerated retreat during the 1980 's, thereby increasing the hazard to shipping because of an increased production of icebergs.

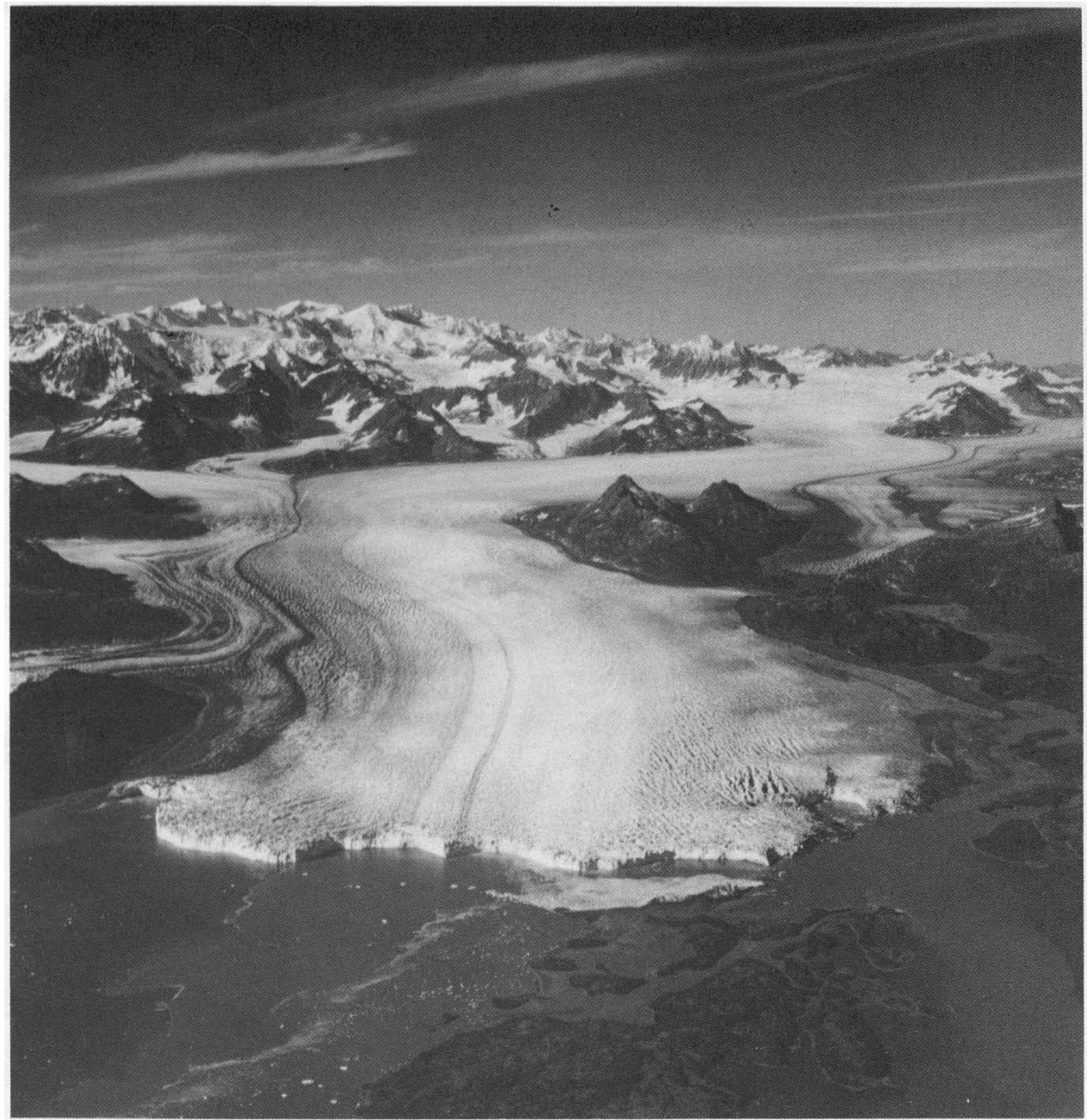

The terminus of the Columbia Glacier, Prince William Sound, Alaska: The glacier located 25 miles (40 kilometers) west-southwest of Valdez, Alaska, is expected to begin a rapid retreat in the early 1980's. By 1986 the glacier is expected to have receded 5 miles (8 kilometers), and the resulting discharge of large numbers of icebergs into shipping lanes serving Valdez, the southern terminus of the trans-Alaskan pipeline, could pose a continuing hazard to the passage of oil tankers (oblique aerial photo by Larry Mayo, August 1, 1976). 
Other glacial hazards include "surging" glaciers. Such glaciers may suddenly advance several miles (several kilometers) in a few months. Catastrophic outburst floods, resulting from the failure of ice-dammed lakes or from subglacial volcanic or geothermal activity, occur frequently in Iceland and in Alaska, less frequently in the State of Washington, and occasionally in other locales.

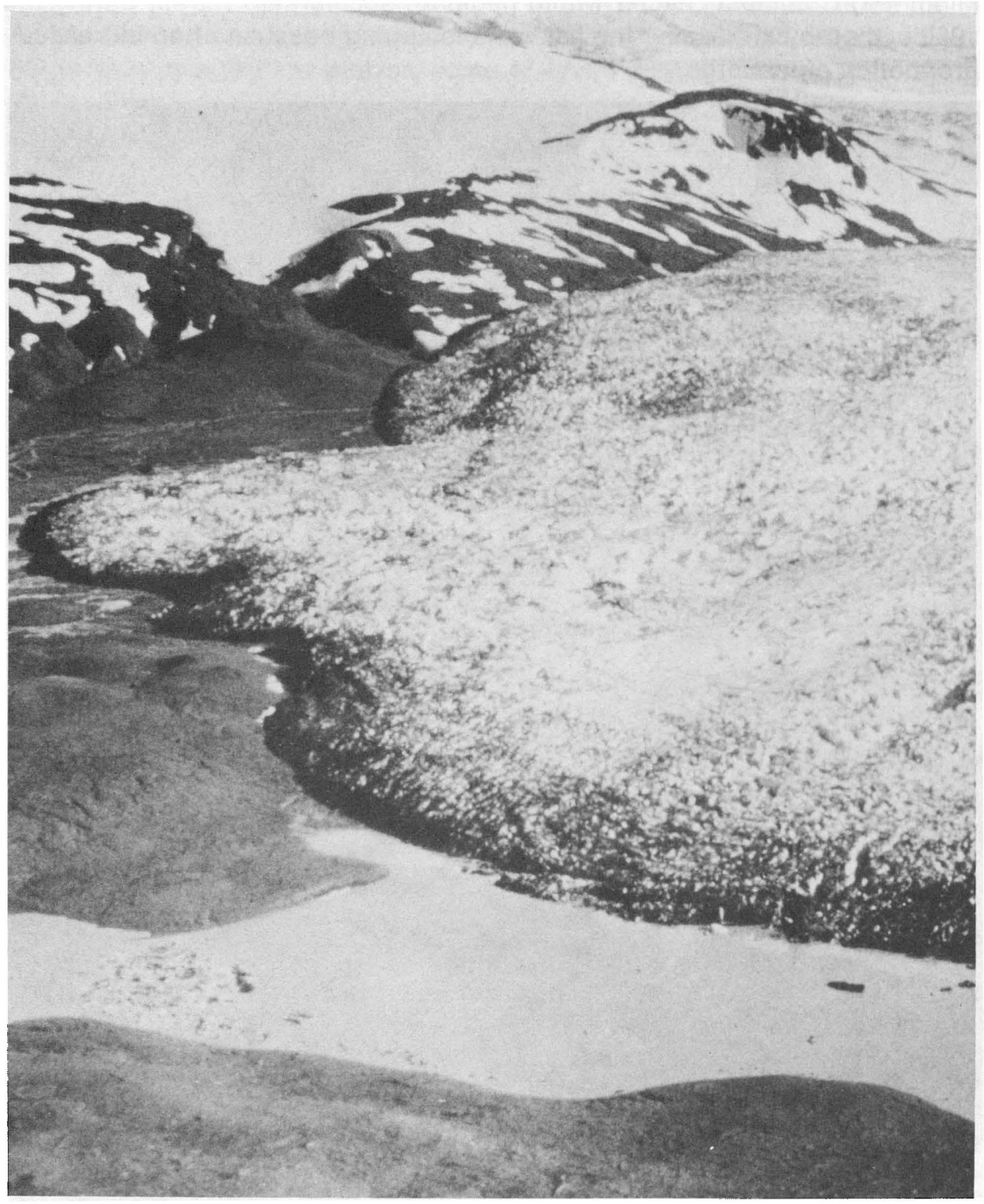

The terminus of Eyjabakkajökull in Iceland is shown after completion of a 2-mile (3-kilometer) surge forward. Note the fragmented nature of the glacier (oblique aerial photo by Richard S. Williams, Jr., July 25, 1973). 
The link between climate and glaciers is of great interest to scientists. Not only have geologists and other scientists established that glaciers were more and less extensive at various times in the past than at present but also that changes in climate were the cause. The enigma, of course, is what causes such changes in climate?

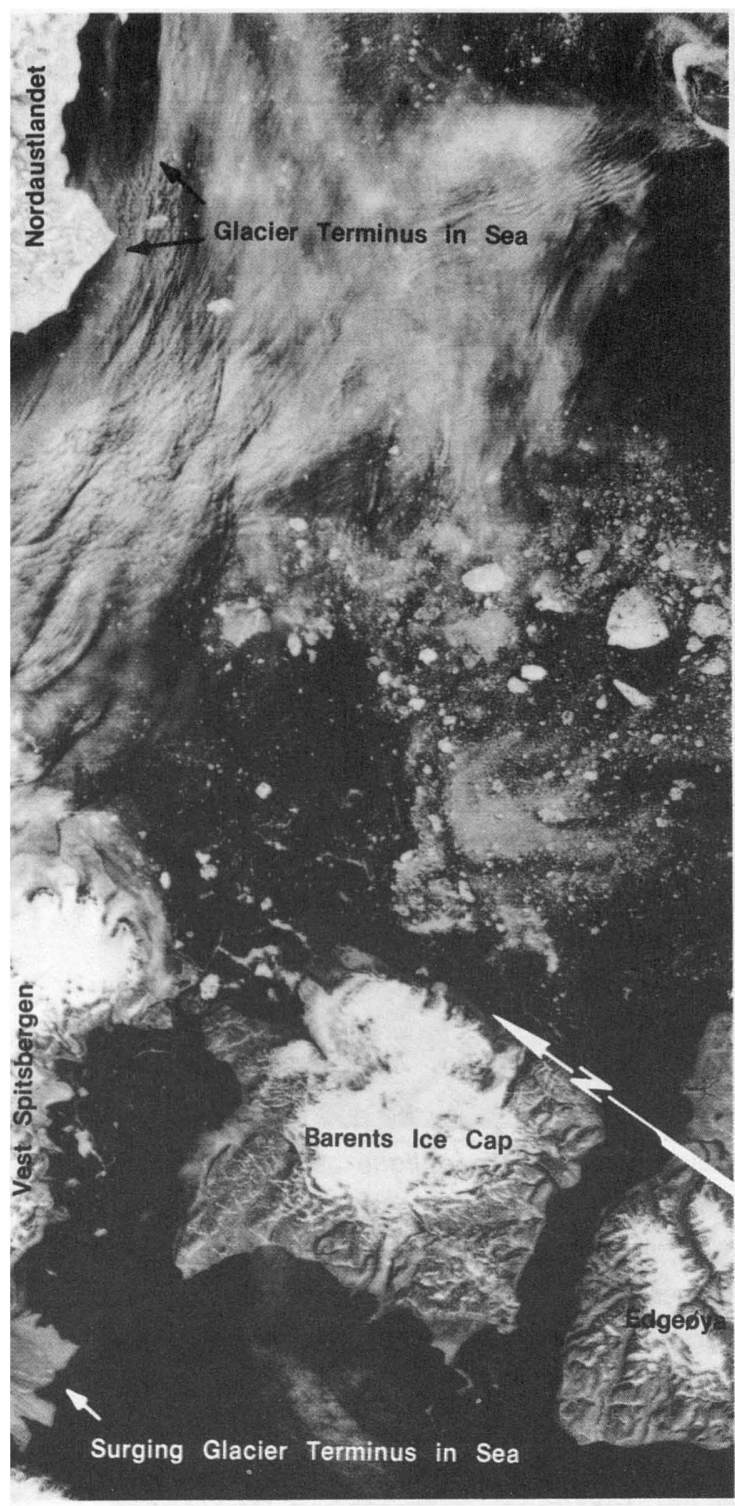

Landsat image of parts of Vest Spitsbergen, Edgeøya, and Nordaustlandet eastern Svalbard, Norway: Several glaciers are shown extending into the sea on July 18 , 1976 (NASA image 2543-11155).

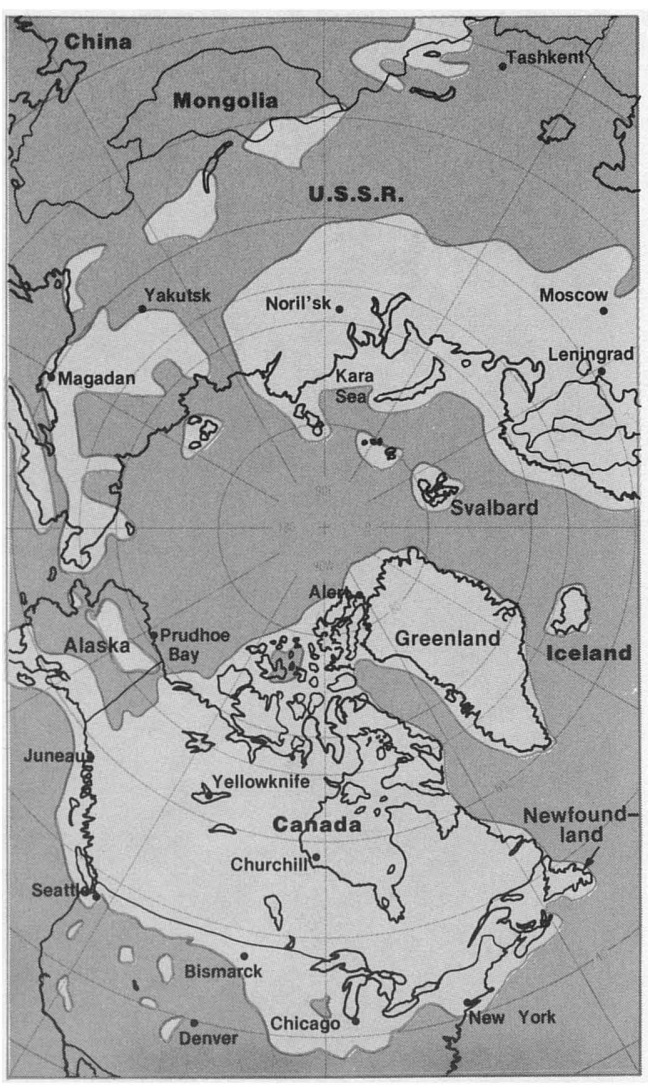

Maximum extent during

Pleistocene Epoch

Map showing the maximum areal extent of glacial ice during the Pleistocene Epoch (lce Age) in the north polar area (from Polar Regions Atlas, May 1978, CIA). 


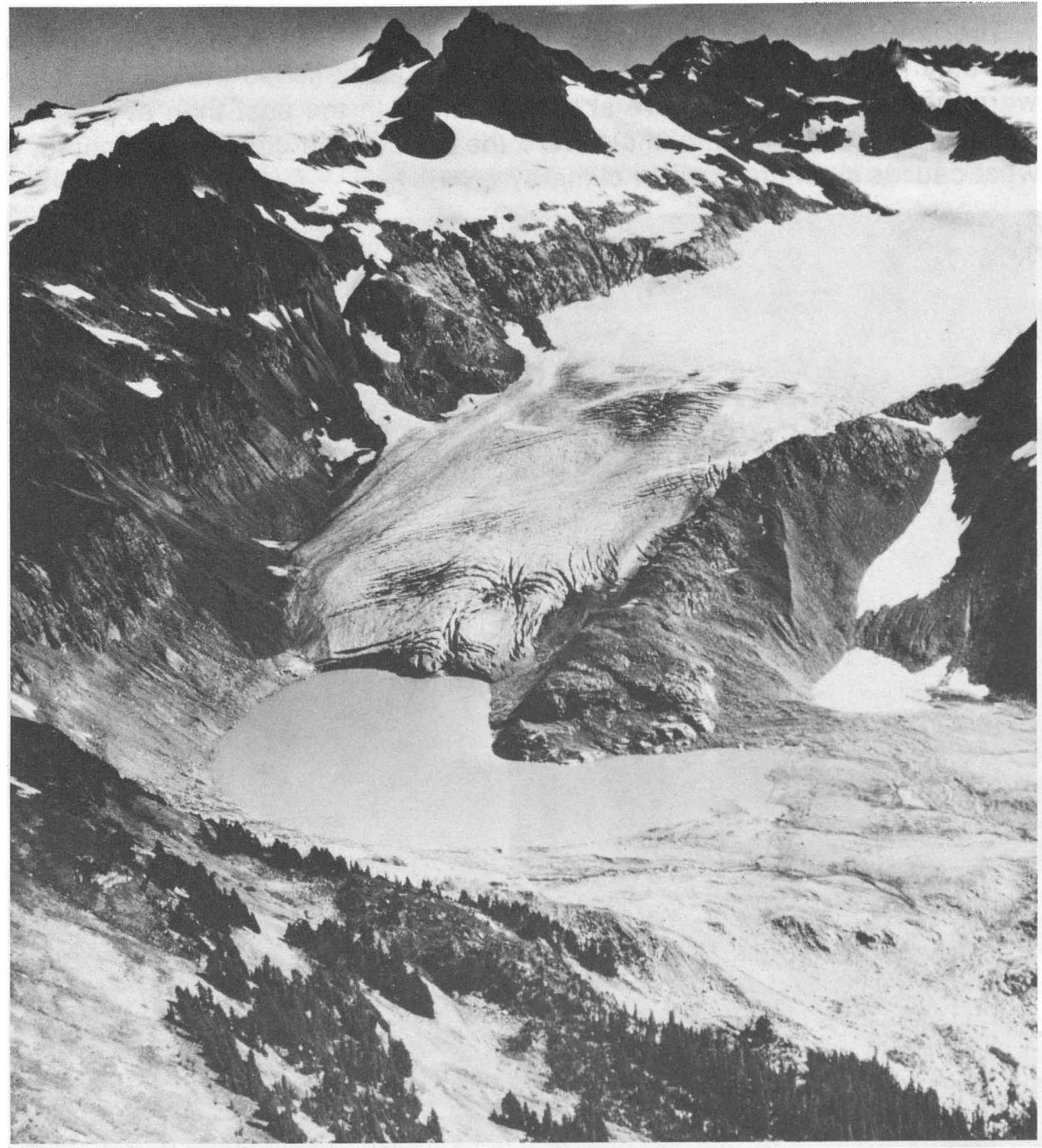

The South Cascade Glacier, Cascade Mountains, Washington (oblique aerial photo by Austin Post, September 23, 1965)

Within the past 3 million years, glaciers-in the form of icecaps and ice sheets-repeatedly advanced to cover as much as 30 percent of the total land area of the Earth. This land area includes most of Canada, all of New England, much of the upper Midwest, large areas in Alaska, all of Greenland, Svalbard, other Arctic islands, Scandinavia, most of Great Britain and Ireland, and much of the western part of northern Russia. Parts of southern South America, central Asia, the Alps, and many other mountainous areas in Asia also experienced an increase in glacier extent. Glaciers in Antarctica also expanded somewhat, but more in ice thickness than in ice area because of the limiting effect of the surrounding oceans. 


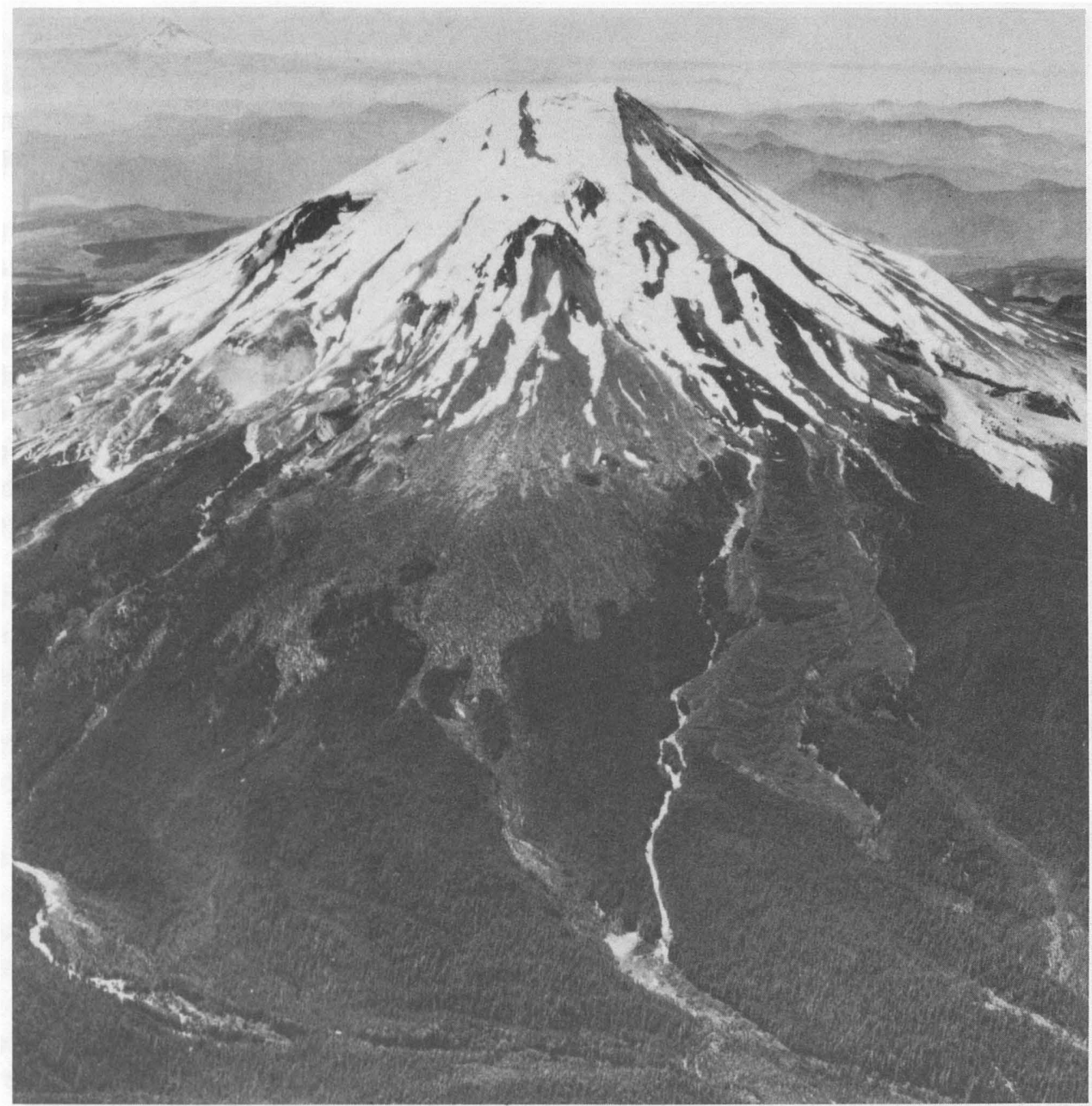

The snow- and glacier-covered Mount St. Helens, Washington, on April 10, 1980, prior to the catastrophic eruption of May 18, 1980.

Although four or five major glacial advances have been identified by geologists who have studied glacial deposits in Europe and North America, stratigraphic evidence from the Tjörnes area of Iceland suggests that as many as 10 major glacial advances may have occurred within the past 3 million years or during what is popularly referred to as the Ice Age.

Geologists recognized during the 19th century that the Earth has been repeatedly subjected to glaciation many times more extensive than the areal distribution of present-day glaciers. More recent evidence, from geochronological evidence (isotopic age dating), has shown that the last continental-size glaciers in Europe, Asia, and North America were still melting away only 10,000 years ago. These findings have caused scientists and nonscientists alike to ask themselves two questions with profound 


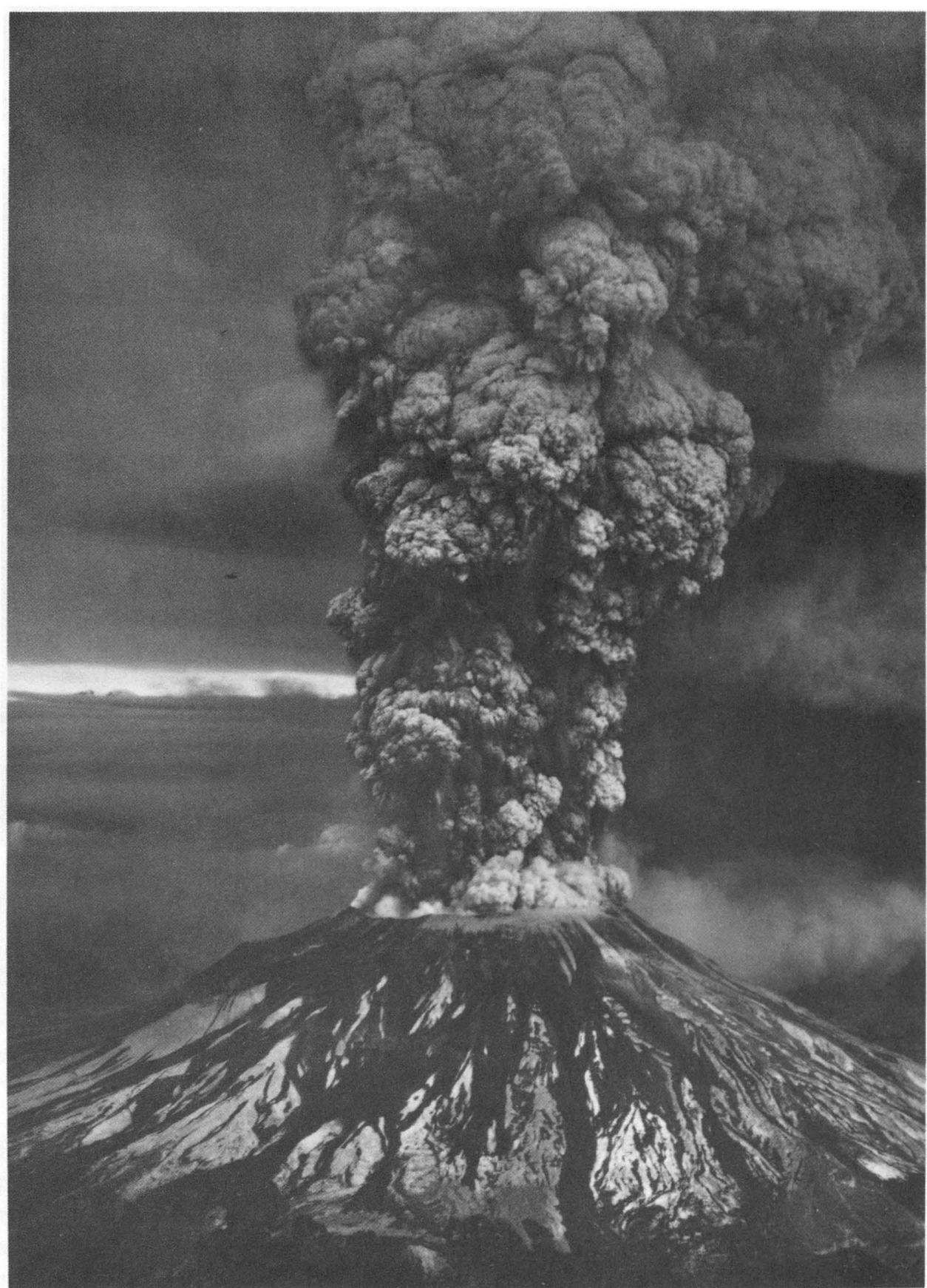

Mount St. Helens, Washington, at about noon on May 18, 1980: The billowing eruption plume of volcanic ash (tephra) and other volatiles emanates from the 1-mile-wide $\left(1 \frac{1}{2}\right.$ kilometers) summit crater and extends well into the stratosphere. Volcanic dust in the stratosphere can reduce the amount of solar energy reaching the Earth's surface. This can result in climatic cooling if such dust veils persist for several months or years. (oblique aerial photo by Robert M. Krimmel). 
implications: What caused the continental glaciers to advance and retreat, and because there have been so many glacial advances within the past 3 million years, is the world still emerging from the last glacial retreat or are we already heading back into the next glacial advance?

Because variation in climate causes glaciers to advance or retreat, glaciers can serve as excellent indicators of climatic change. Geologists and other scientists study sedimentary deposits on land and in the sea to determine how long glacial intervals lasted, the frequency of repetition, the length of interglacial intervals, the variation in ocean surface temperature during the past 3 million years, and many other factors. These empirical or observational data are then compared with the various theories of glaciation to attempt to ascertain the actual causes of glaciation and to identify the clues to look for in determining whether we are still coming out of or going back into a glacial interval.

Among the more prominent theories of events that have triggered global climatic changes and lead to repeated glaciation are: (1) known astronomical variations in the orbital elements of the Earth (the so-called Milankovitch theory); (2) changes in energy output from the Sun; and (3) increases in volcanism that could have thrown more airborne volcanic material into the stratosphere, thereby creating a dust veil and lowered temperatures.

The years 1980,1981 , and 1982, for example, saw several major volcanic eruptions adding large quantities of particulate volcanic material and volatiles to the stratosphere, including the catastrophic eruption of Mount St. Helens, Wash., on May 18, 1980, and a large eruption of Mount Hekla, Iceland, on August 17, 1980. The 1982 series of eruptions from El Chichón volcano, Mexico, caused death and destruction in the populated area around the volcano, but a further reaching impact may result from the effect on Earth's climate because of the enormous ejection of volcanic material into the stratosphere.

The potential climatic effect of the Laki volcanic eruption in Iceland in 1783 , the largest effusive (lava) volcanic eruption in historic time, was noted by the diplomat-scientist Benjamin Franklin in 1784, during one of his many sojourns in Paris. Franklin concluded that the introduction of large quantities of volcanic particles into the Earth's upper atmosphere could cause a reduction in surface temperature, because the particles would lessen the amount of solar energy reaching the Earth's surface. The catastrophic eruption of the Tambora volcano, Indonesia, in 1815 was followed by a so-called "year-without-a-summer." In New England, for example, frost occurred during each of the summer months in 1816.

Some of the observational evidence matches certain aspects of these three theories and other theories as well. Whatever the actual cause or causes of climatic change, the irrefutable fact is that repeated periods of glaciation have occurred, and that the last such glacial interval ended in the geologically recent past-at the dawn of human civilization. 


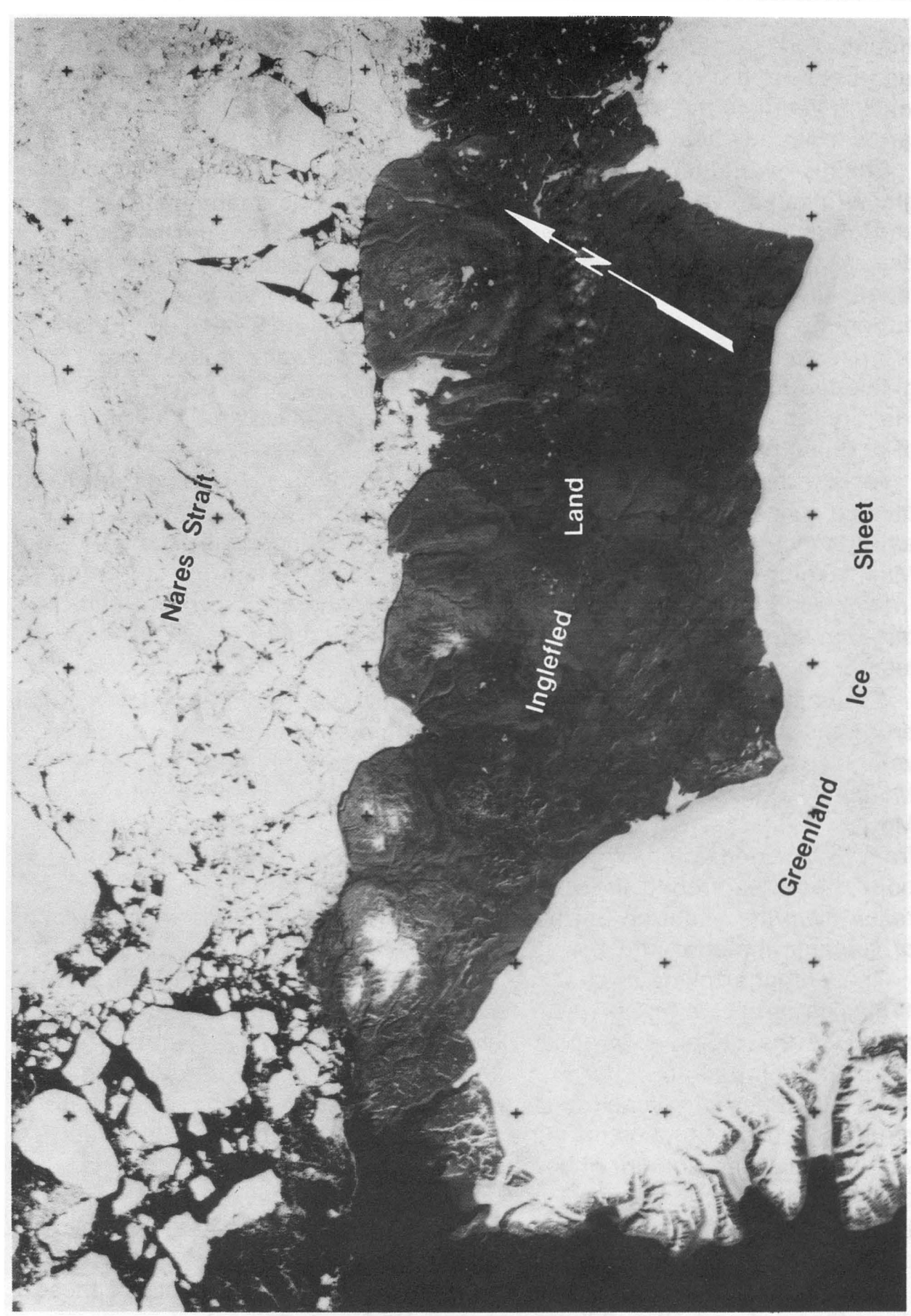

Landsat image of northwestern Greenland on July 29, 1976, shows the well defined edge of the Greenland Ice Sheet in the Inglefield Lard area and numerous outlet glaciers emptying into fiords. Sea ice fills the Nares Strait between Greenland and Ellesmere Island, Northwest Territories, Canada (NASA image 2554-17283). 


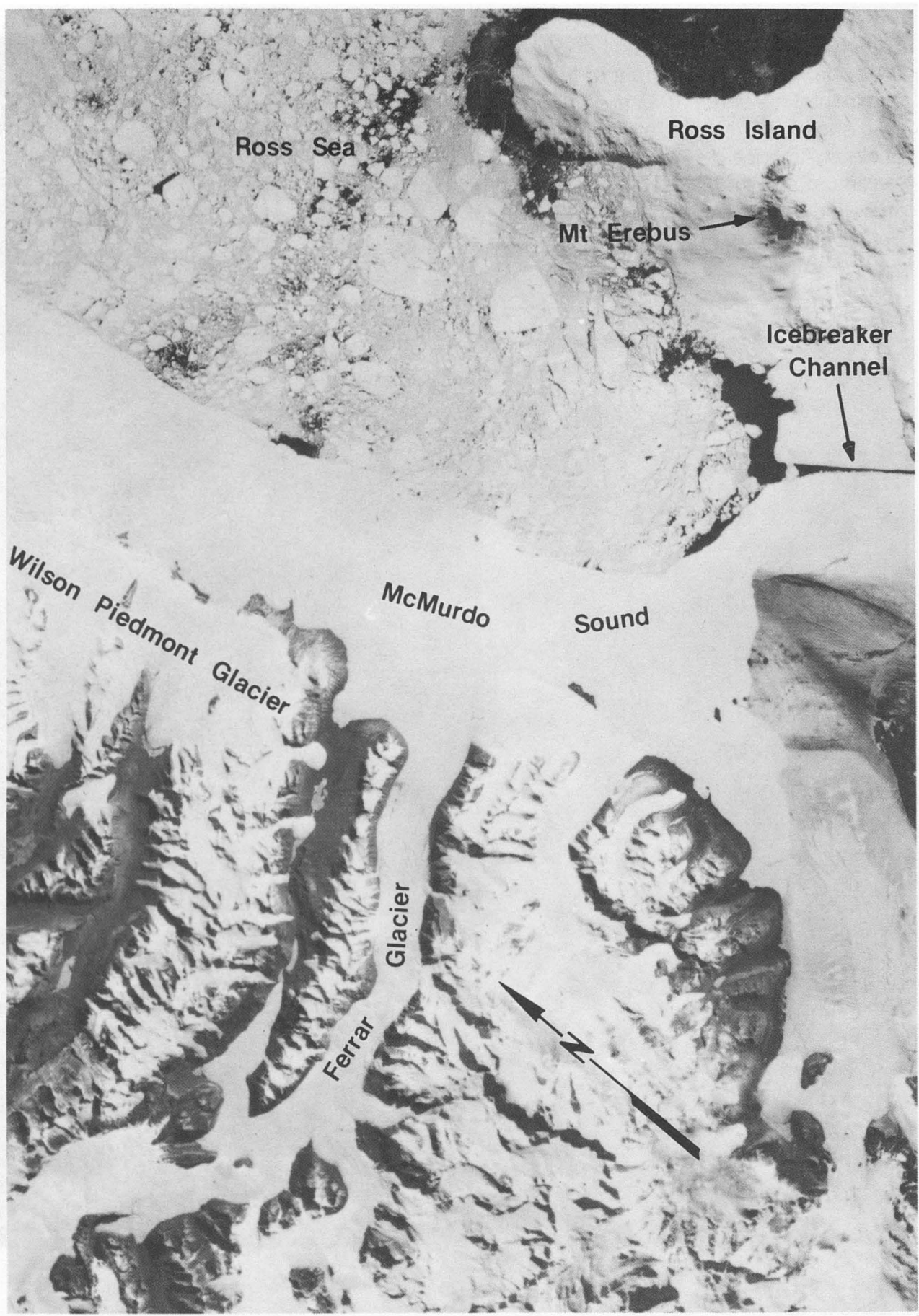

Landsat image of the McMurdo Sound area, Antarctica, location of the primary U.S. scientific and logistics base in Antarctica: This image was used for the first Landsat image map of Antarctica (1:500,000 scale), published by the U.S. Geological Survey in 1978 (NASA image 1174-19433, January 13, 1973). 
Sketch map of North America shows the approximate areal extent of the continental ice sheet at its maximum. Also shown is the postulated coastline of North America during this glacial

maximum and the present-day shoreline (dashed line) (from USGS

Yearbook, $\dot{F} Y$ 1979).

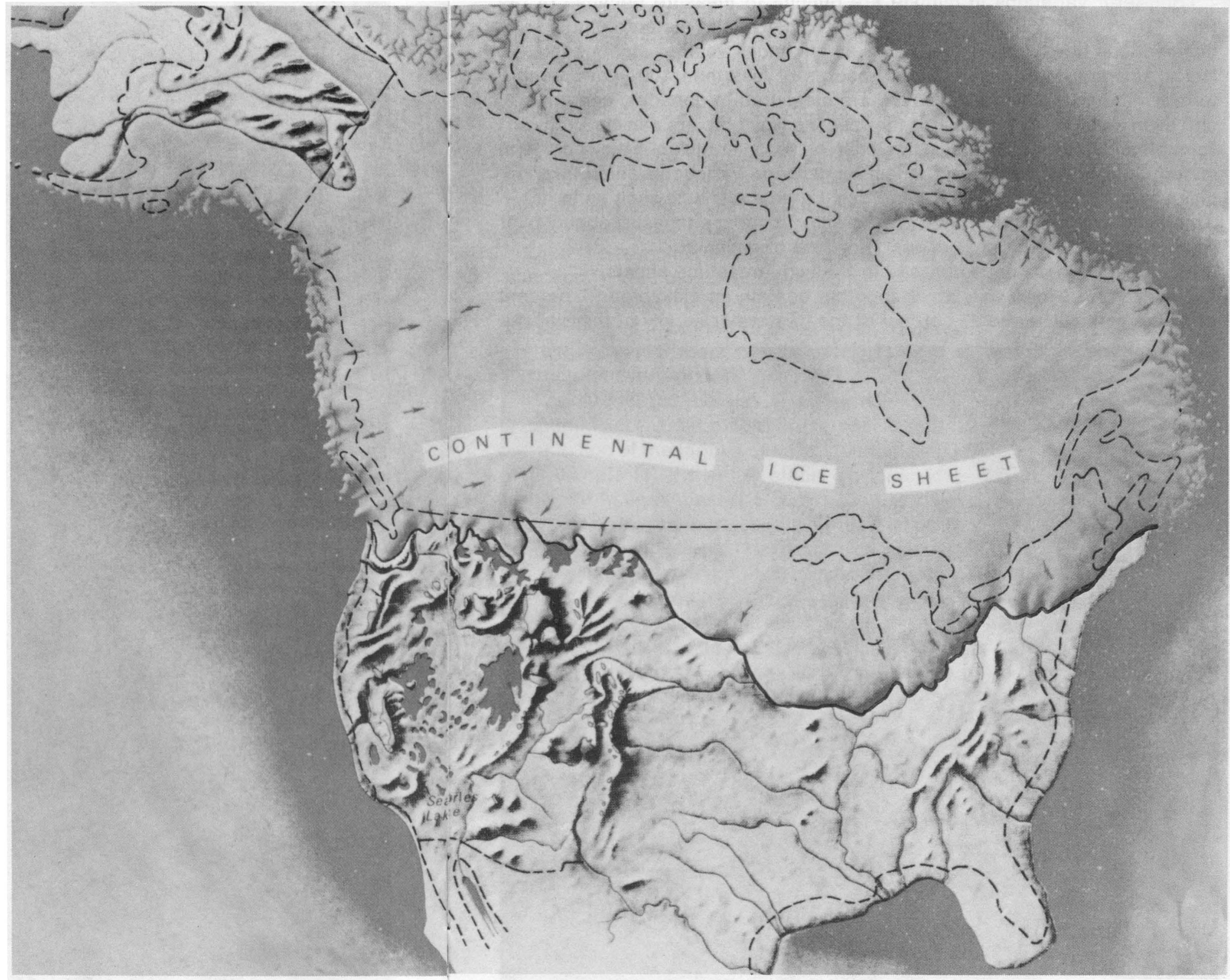


Long-term variations in climate are difficult to measure because of the rather short period of time in which scientifically valid meteorological observations have been made. For example, most weather stations in North America have observational records of less than 100 years. Longterm variations in climate, however, are measured in decades, centuries, and even millenia. This is one of the reasons why glaciers can be such valuable indicators of climate. Glaciers tend to "average" out the short term meteorological variations and reflect longer term variations which take place over several decades or centuries. Large ice sheets such as in Greenland and Antarctica have even greater response times, probably over several millenia (thousands of years) or tens of millenia.

Most glacial ice is encompassed in the two largest ice sheets, Antarctica and Greenland, which together contain an estimated 97 percent of all the glacial ice and 77 percent of the freshwater supply of the planet.

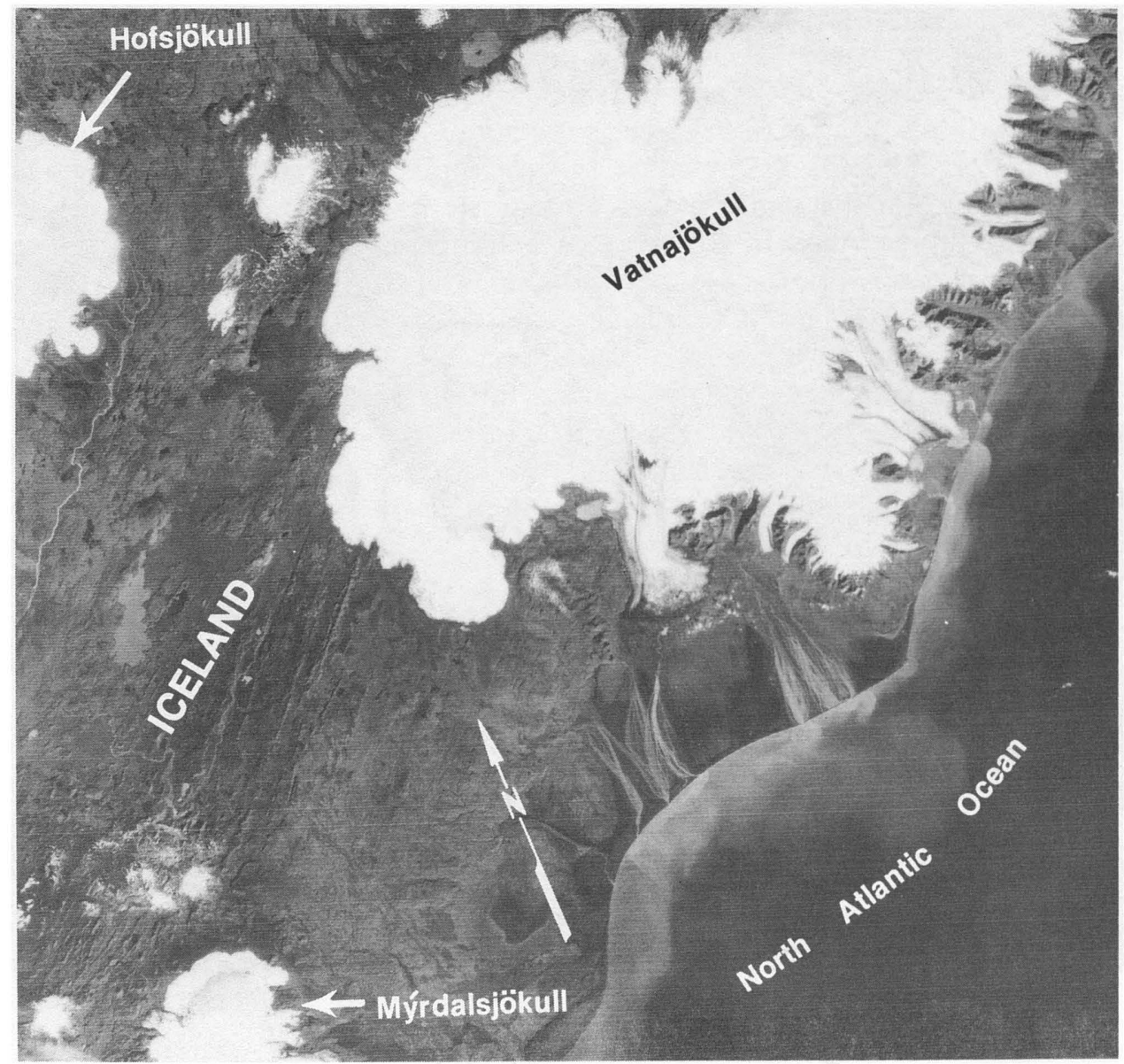

Landsat image of Vatnajökull, Sept. 22,1973 , the largest-3,200 square miles $(8,300$ square kilometers)-icecap in Iceland: Repetitive Landsat images of Vatnajökull, acquired since 1972, have enabled glaciologists to monitor dynamic changes of this icecap in a timelapse manner (NASA image 1426-12070). 
During a maximum global advance of glaciers, however, it is estimated that North America contained volumetrically more ice than the combined present-day total of Antarctica and Greenland, and that sea level dropped by as much as $\mathbf{3 0 0}$ feet ( 90 meters). If all the present glacial ice were to melt from Antarctica and Greenland, the oceans would rise another 300 feet (90 meters) and inundate most of the coastal cities of the world. Some glaciologists have suggested that the West Antarctic Ice Sheet is inherently unstable and could suddenly surge forward under climatic conditions similar to the present time, resulting in a 7 to 20 feet (2-6 meters) global rise in sea level, depending on the size of the surge.

Until the launches in 1972, 1975, 1978, and 1982 of the Landsat series of spacecraft, glaciologists had no accurate means of measuring the areal extent of glacial ice on Earth. Landsat 1, 2, and 3 multispectral scanner (MSS) images, obtained from an orbital altitude of 570 miles (920 kilometers), covered about the same area, 10,000 square miles $(34,000$ square kilometers) every 18 days, and had a pixel (picture element) resolution of about 260 feet ( 80 meters). Such satellite images provide a means for delineating the areal extent of ice sheets and icecaps and for determining the position of the termini of valley, outlet, and tidal glaciers on a common base of data for the entire globe. To take advantage of this data, a "Satellite Image Atlas of Glaciers" is being prepared by the U.S. Geological Survey in association with a number of other U.S. and foreign scientific organizations. If Landsat-type surveys of the planet are continued for several decades, a means of monitoring long-term changes in glacial area will also become possible-thereby giving us a way of monitoring global climate change.

Iceland, an island in the North Atlantic at about $65^{\circ}$ North latitude, is about the size of the Commonwealth of Virginia or about 40,000 square miles $(103,000$ square kilometers). About 10 percent of the area of Iceland is covered by glaciers, mostly occurring as icecaps of various sizes, the largest of which is Vatnajökull, with an area of about 3,200 square miles $(8,300$ square kilometers). Six other glaciers have areas in excess of 19 square miles (50 square kilometers). Many of the icecaps of Iceland, such as Vatnajökull, Langjökull, Hofsjökull, Mýrdalsjökull, and Eyjafjallajökull, are extremely dynamic, with heavy annual accumulations of snow-over 20 feet ( 6 meters) per year in the interior of Vatnajökull. Rapid movement is nearly 6 feet ( 2 meters) per day in one of the outlet glaciers of Vatnajökull, and extensive melting occurs at lower elevations.

For a variety of reasons the glaciers of Iceland are well suited to serve as an indicator of changes in climate in at least the Northern Hemisphere. The historical record of pre-1900 observations has been well documented over the years by several Icelandic scientists such as Thoroddsen and Thorarinsson. The Danish Geodetic Survey began to survey and produce maps of Iceland in the early part of the 20th century just after the end of 
Historical Changes in the Areas of Selected Icelandic Glaciers

\begin{tabular}{|c|c|c|c|c|c|c|c|c|c|}
\hline \multirow[b]{2}{*}{ Glacier Name } & \multicolumn{2}{|c|}{$\begin{array}{c}\text { A } \\
\text { *Thoroddsen } \\
\text { (1906) }\end{array}$} & \multicolumn{2}{|c|}{$\begin{array}{c}\text { B } \\
\text { **arinsson } \\
\text { (1943) }\end{array}$} & \multicolumn{2}{|c|}{$\begin{array}{c}\text { C } \\
\text { **Thorarinsson } \\
\text { (1958) }\end{array}$} & \multicolumn{2}{|c|}{$\begin{array}{c}\text { D } \\
* * * \text { Williams }\end{array}$} & \multirow{2}{*}{$\begin{array}{c}\text { E } \\
\text { Percentage } \\
\text { Decrease } \\
\text { (C - D ) }\end{array}$} \\
\hline & $m i^{2}$ & $\left(\mathrm{~km}^{2}\right)$ & $\mathrm{mi}^{2}$ & $\left(\mathrm{~km}^{2}\right)$ & $\mathrm{mi}^{2}$ & $\left(\mathrm{~km}^{2}\right)$ & $\mathrm{mi}^{2}$ & $\left(\mathrm{~km}^{2}\right)$ & \\
\hline Vatnajökull & 3282 & $(8500)$ & 3247 & (8410) & 3272 & (8475) & 3204 & $(8300)$ & $-2 \%$ \\
\hline Langjökull & 502 & $(1300)$ & 394 & (1021) & 395 & (1022) & 368 & (953) & $-7 \%$ \\
\hline Hofsjökull & 521 & (1350) & 381 & (987) & 385 & (996) & 357 & (925) & $-7 \%$ \\
\hline \multirow{2}{*}{$\begin{array}{l}\text { Myrdalsjökull } \\
\text { Eyjafjallajökull }\end{array}$} & \multirow{2}{*}{386} & \multirow{2}{*}{$(1000)$} & 264 & (685) & 271 & (701) & 230 & (596) & $-15 \%$ \\
\hline & & & 39 & (101) & 41 & (107) & 30 & $(771 / 2)$ & $-28 \%$ \\
\hline $\begin{array}{l}\text { * Based on } \\
\text { Map of Ic } \\
\text { ** From Dan } \\
\text { *** From } 19\end{array}$ & $\begin{array}{l}\text { Geod (fr } \\
\text { Get al }\end{array}$ & $\begin{array}{l}\text { gsson's } \\
\text { n 1881-1 } \\
\text { etic Inst } \\
22 \text { Sep }\end{array}$ & $\begin{array}{l}898 \text { fiel } \\
\text { tute Ma } \\
\text { tember }\end{array}$ & $\begin{array}{l}\text { surveys } \\
\text { s (1902- } \\
973 \text { Lan }\end{array}$ & $\begin{array}{l}938 \text { ar } \\
\text { sat im }\end{array}$ & $\begin{array}{l}\text { post-V } \\
\text { es of I }\end{array}$ & $\begin{array}{l}\text { rld } Y \\
\text { land. }\end{array}$ & 1901 & eological \\
\hline
\end{tabular}

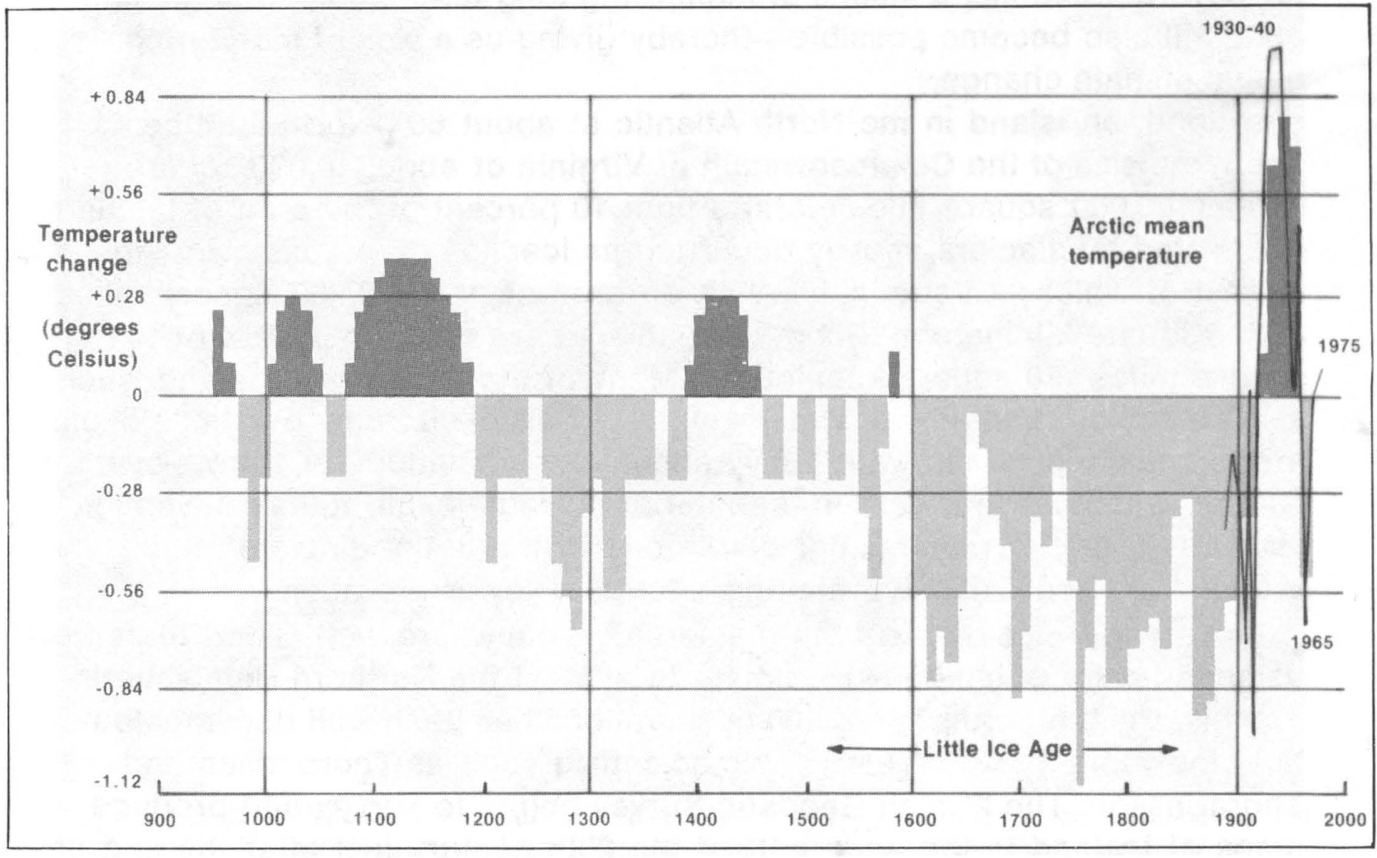

A thousand-year history of Iceland's temperature (from Polar Regions Atlas, May 1978, CIA). 
what is now called "The Little Ice Age," the cool climatic period between about the mid-1500's and the late 1800's. Many of the terminal moraines deposited by Iceland's glaciers most distant from the present-day ice margins (termini) were formed during the latter part of the 19th century. The warmer first half of the 20th century has seen all of Iceland's glaciers diminish in size in response to this period of climatic warming. For example, Glámujökull, an ice cap in northwest Iceland, which appeared on late 19th century and early 20th century maps with an area of 89 square miles (230 square kilometers) and 1.7 square miles (4.5 square kilometers), respectively, has subsequently completely disappeared and no longer appears on modern maps.

U.S. military maps were made during the 1940's, and a revised map series is presently in production. The Iceland Geodetic Survey has also published revised maps and has begun a new series of orthophotomaps in association with the United States. Landsat images of Iceland permit an excellent means of monitoring changes in the area of Icelandic glaciers at more frequent intervals. Already, Landsat images of Iceland have been used to good advantage by U.S. Geological Survey and Icelandic scientists to document changes resulting from two glacial surges; the velocity of an outlet glacier has been measured, and existing maps have been revised.

According to Milankovitch and other 20th century theoretical climatologists, the glaciers in the area around $65^{\circ}$ North latitude are especially sensitive to astronomical variations in the orbital elements of the Earth. In the Northern Hemisphere, glaciers on Baffin Island, Canada; in the Alaska Range, Alaska; in the southern tip of Greenland; in Iceland; and in Norway are at the right location. Except for Greenland, with its massive ice sheet, all the other geographic areas mentioned contain only remnants of a once far more extensive glacial ice cover during the Pleistocene. The glaciers of Iceland, as with some of those in these other areas, are important as long-term indicators of climatic change because of their latitudinal location and because they are apparently just large enough not to be affected by short-term climatic variation yet are small and dynamic enough to respond to changes caused by climatic variation over several decades. Landsat images of Iceland and other areas at $65^{\circ}$ North latitude are providing a practical and cost-effective means of making a rapid inventory of changes in glacial area.

The Earth can be considered a natural "spaceship" as it and other planets and stars of the galaxy travel through the universe. Climate is one aspect of the planetary environment which has an impact on every living thing; even a small change in climate can have a devastating effect on plant and animal life and on humans and their economies. Because climatic changes have global significance, scientists judiciously search for the correct clues to these changes. This search often requires making observations in remote areas-both on land and in the sea. 
Only recently have scientific tools been developed that can make the necessary observations. With improved technology for extracting cores from the sea bottom and with existing and planned Earth resources survey satellites, geologists, glaciologists, and other scientists now have the tools to study and monitor a variety of environmental factors and phenomena. Many decades of observations by many scientists will be necessary, however, to begin to unravel the climate-glacier puzzle. But a start has been made to try to understand the enigma of climatic change and to understand the response of glaciers to such change. In turn, by studying the response and changes in glaciers, we can better understand-and anticipate-the range of past and possible future climatic changes. Scientists of the U.S. Geological Survey are among those who are deeply involved in the study of the many facets of an incredibly complex environmental problem, one which has extraordinary significance to the economic well being of human societies.

Changes in climate over time produce variations in seasonal and annual temperature and precipitation at different latitudes, a fact confirmed by the geologic record and by meteorological observations during the past 200 years or so. Floods, droughts, higher space heating and cooling costs, variations in agricultural yield, higher snow removal costs, changes in sea level, and variation in length of time of ice-free conditions in navigable waterways have an impact on the economics of various human endeavors. The monitoring of glaciers gives scientists one of the most important indicators in determining whether observed climatic change is regional or global. This knowledge can then be used by governments to make long-range plans to better cope with the economic impact of such climatic changes.

This publication is one of a series of general interest publications prepared by the U.S. Geological Survey to provide information about the earth sciences, natural resources, and the environment. To obtain a catalog of additional titles in the series "Popular Publications of the U.S. Geological Survey," write:

Eastern Distribution Branch or U.S. Geological Survey 604 South Pickett Street Alexandria, VA 22304

Western Distribution Branch U.S. Geological Survey Box 25286, Federal Center Denver, CO 80225 
As the Nation's principal conservation agency, the Department of the Interior has responsibility for most of our nationally owned public lands and natural resources. This includes fostering the wisest use of our land and water resources, protecting our fish and wildlife,

preserving the environmental and cultural values of our national parks and historical places, and providing for the enjoyment of life through outdoor recreation. The Department assesses our energy and mineral resources and works to assure that their development is in the best interests of all our people. The Department also has a major responsibility for American Indian reservation communities and for people who live in Island Territories under U.S. administration. 